\title{
PERMINTAAN ENERGI LISTRIK MASYARAKAT INDUSTRI DAN INDIVIDU PADA PT. PLN PERSERO WILAYAH IX AMBON
}

\author{
Eduard Yohannis Tamaela \\ Sekolah Tinggi Ilmu Ekonomi Dan Manajemen (STIEM) Rutu Nusa Ambon
}

\begin{abstract}
Abstrak
Kota Ambon merupakan Ibu Kota Provinsi Maluku dan merupakan pusat pendidikan, pemerintahan, perdagangan sehingga memacu arus urbanisasi. Pertambahan jumlah penduduk akan mempengaruhi permintaan energi listrik baik masyarakat individu, masyarakat industri, pemerintah dan sosial. Berdasarkan hasil analisa dengan menggunakan program SPSS temyata untuk masyarakat individu nilai $\mathrm{b}_{1}$ (harga pemasangan instalasi) sebesar 9.904, nilai $b_{2}$ (penduduk) $=3.431$ selanjutnya nilai $b_{3}$ (pendapatan perkapita $)=4.388$ artinya nilai elastisitas berpengaruh secara signifikan. Diamati dari nilai hubungan (regresi) ternyata memberikan sumbangan $r=1$ sedangkan nilai korelasi $r^{2}=99,9$ artinva variabel $x_{1}, x_{2}, x_{3}$ (harga pemasangan, penduduk, pendapatan perkapita) sangat berpengaruh terhadap peningkatan pemutusan energi listrik bagi konsumen masyarakat individu. Selanjutnya untuk masyarakat industri ternyata diperoleh nilai $b_{1}=(-5,900)$ kemudian nilai $b_{2}=2.383$ selanjumya nilai $b_{3}=1,296$ artinya variabel yang sangat berpengaruh adalah variabel penduduk dan pendapatan perkapita.
\end{abstract}

Kata kunci : permintaan energi lstrik, masyarakat individual, masyarakat industri

Pertumbuhan permintaan tenaga energi listrik sangat berguna bagi peningkatan kesejahteraan masyarakat yakni pembangunan kehidupan berbangsa maupun bernegara. Hal ini dibuktikan dengan kenyataan bahwa adanya kemajuan teknologi dengan segala kecanggihannya dalam kaitan dengan penggunaan alatalat produksi baik bagi perusahaan maupun rumah tangga individu. Kebutuhan akan tenaga listrik bahkan sudah semakin menjadi kebutuhan primer yang dikonsumsikan oleh seluruh lapisan masyarakat tanpa kecuali.

Guna pemanfaatan listrik secara maksimal atau dapat dinikmati oleh seluruh lapisan masyarakat diperlukan suatu kebijaksanaan, strategi dan usaha yang didasarkan pada sifat-sifat karakteristik suatu wilayah termasuk daerah Maluku dan khususnya Kota Ambon. Menurut UU No 15 Tahun 1985; 
penguasaan, pengesahan penyediaan tenaga listrik harus dilakukan oleh negara yang didirikan atas dasar peraturan-peraturan perundang-undangan. Pemegang Kekuasaan Urusan Kelistrikan (PKUK) sampai dengan saat ini adalah Perusahaan Listrik Negara (PLN) yang diberikan kewenangan sebagai Badan Usaha Milik Negara (BUMN).

Salah satu faktor yang turut mempengaruhi permintaan energi listrik yaitu bahwa biaya yang dikeluarkan oleh perusahaan untuk memperoleh faktorfaktor produksi yang digunakan oleh perusahaan yang merupakan proses transformasi dalam perjalanan waktu yang ditandai oleh perubahan struktur yaitu landasan ekonomi yang kuat (Sadono Sukirno, 2002: 205). Dengan demikian, pembangunan tenaga listrik sebagai salah satu faktor penunjang pembangunan ekonomi perlu ditunjukan dengan konstribusi bagi pendapatan perkapita dan akan menciptakan masyarakat yang adil dan makmur. Sedangkan menurut Sisjatmoko Kusumosuwidho (dalam Soediyono: 1992) mengatakan bahwa : "Permintaan dari suatu barang adalah banyaknya barang yang diharapkan untuk dibeli bagi seluruh rumah tangga pada suatu harga tertentu dengan asumsi bahwa hal-hal seperti harga barang lain, pendapatan konsumen dan selera tidak berubah"

Fungsi permintaan akan suatu barang dapat didefenisikan sebagai fungsi yang menunjukan hubungan antara jumlah suatu barang yang terbeli persatuan waktu dengan berbagai nilai dari pada dua atau lebih variabel yang turut menetukan jumlah barang tersebut (Soediyono, 1992:112). Permintaan akan suatu barang tertentu bersumber pada kebutuhan konsumen. Orang mau membeli barang/jasa tersebut berguna untuknya, yaitu dapat memenuhi salah satu kebutuhannya. Sebab permintaan yang dilayani oleh pasar adalah permintaan yang efektif (kebutuhan yang ada didukung oleh ketersediaan dan kemampuan untuk membayar harganya).

Pendapatan merupakan salah satu faktor yang penting dalam kehidupan manusia karena pendapatan merupakan daya beli didalam pemenuhan kebutuhan hidup. Dengan demikian seseorang berusaha melaksanakan berbagai kegiatan untuk menperoleh pendapatan seperti ada yang melibatkan tenaga dan hartanya dalam suatu kegiatan produksi. Gardner Ackley mendefenisikan pendapatan sebagai berikut: "Pendapatan seseorang individu dapat didefenisikan sebagai 
suatu penghasilan yang diperolehnya dari jasa produksi yang ada pada suatu waktu tertentu atau diperoleh dari harta kekayaan”.

Bertolak dari pendapat diatas, maka dapat dikatakan bahwa yang diartikan dengan pendapatan adalah seluruh penghasilan yang diperoleh setelah dikurangi dengan kewajiban-kewajiban yang merupakan hasil balas jasa atau faktor-faktor produksi yang telah dilibatkan dalam suatu jangka waktu tertentu dan biasanya dinyatakan dengan uang. Pendapatan sendiri terdiri atas beberapa jenis, yaitu: pendapatan nasional (national income), pendapatan perorangan (personal income), dan pendapatan disposibel (disposible income), selanjutnya untuk memperinci, maka dapat dikemukakan perbedaan ketiga pendapatan tersebut: pendapatan seorang individu dapat didefenisikan sebagai jumlah penghasilan yang diperolehnya dari jasa-jasa produksi yang diserahkan pada suatu waktu tertentu atau diperolehnya dari harta kekayaan.

Pendapatan nasional tidak lebih dari jasa-jasa produksi yang sebenarnya bukan hak pendapatan pada tahun yang bersamaan seperti: subsidi, pensiun, bunga, dan sebagainya. Pendapatan diposible merupakan pendapatan yang benarbenar diterima dan siap dibelanjakan sesuai keinginan mereka atau ditabung dan pendapatan tersebut adalah pendapatan yang terjadi di masa yang akan datang.

Dalam kehidupan ekonomi modern harga mempunyai peranan yang sangat penting, justru karena produsen dan konsumen yang didalamnya termasuk dunia perbankan dan juga pemerintah yang bertindak atas dasar pertimbangan dan perbandingan harga. Alex S. Nitisemito (1982:55) mengemukakan pengertian harga adalah sebagai berikut: "nilai suatu barang atau jasa yang diukur dengan sejumlah uang berdasarkan nilai barang atau jasa tersebut oleh seorang atau perusahaan yang bersedia melepaskan barang yang dimilikinya kepada pihak lain”. Seorang produsen tidak akan menjual barang yang dihasilkannya dengan harga kurang dari biaya produksi. Olehnya itu dapat dikatakan bahwa harga ditentukan oleh kedua-duanya bersama yaitu dalam interaksi antara produsen dan konsumen.

Sistem harga merupakan alat pembantu yang sangat penting untuk memecahkan persoalan ekonomi. Namun dilain pihak saat terjadi inflasi dan resesi, yang disebabkan oleh harga yang sering naik turun, justru sistem harga 
dan pasar kurang dapat berfungsi dengan baik. Hal ini karena harga tidak dibarengi dengan pertambahan produksi. Dalam mengatasi setiap permasalahan yang terjadi diperlukan campur tangan pemerintah untuk mengatur produksi, distribusi, konsumsi, mengawasi keuangan dan perkreditan, menjaga kestabilan harga khususnya barang kebutuhan pokok. (Gilarso, 1993: 63).

Secara umum pemerintah mengadakan prasarana-prasarana yang perlu agar sistem harga bisa berfungsi dengan baik, antara lain dengan menjaga keamanan dan tertib hukum, mengusahakan tersedianya fasilitas pasar, transport, komunikasi, pengkreditan serta mengawasi harga-harga barang. Khususnya menganai harga, pemerintah dapat mempengaruhi harga harga melalui permintaan dan penawaran yaitu dengan memasuki pasar dan bertindak sebagai pembeli dan penjual. Pemerintah dapat juga langsung menetapkan harga lepas dari permintaan dan penawaran.

Dari konseptual toeri yang dijelaskan diatas menggambarkan bahwa fenomena permintaan listrik di Kota Ambon juga mempengaruhi proses pembangunan dan pengembangan ekonomi dalam kaitan proses transformasi sebagai upaya penguatan landasan ekonomi di wilayah tertentuakan semakin dibutuhkan. Di kota Ambon, penggunaan listrik untuk rumah tangga industri pangan atau konsumen rumah tangga individu jumlahnya lebih besar yang tentunya akan menentukan juga besarnya penerimaan PT. PLN. Dari jenis pelanggan listrik yang diamati adalah masyarakat individu dan masyarakat industri seperti pada tabel berikut:

Tabel 1

Perkembangan Jumlah Pelanggan Listrik untuk Rumah Tangga Industri dan Rumah TanggaIndividu di Kota Ambon

Tahun $2004-2008$

\begin{tabular}{|c|c|c|c|c|}
\hline \multirow{2}{*}{ Tahun } & \multicolumn{4}{|c|}{ Jumlah Pelanggan } \\
\cline { 2 - 5 } & $\begin{array}{c}\text { Rumah Tangga } \\
\text { Industri } \\
\text { (Perusahaan) }\end{array}$ & $\begin{array}{c}\text { Pertumbuhan } \\
(\%)\end{array}$ & $\begin{array}{c}\text { Rumah Tangga } \\
\text { Individu } \\
\text { (KK) }\end{array}$ & $\begin{array}{c}\text { Pertumbuhan } \\
(\%)\end{array}$ \\
\hline 2004 & 35 & - & 110.957 & - \\
2005 & 37 & 5,71 & 113.387 & 2,19 \\
2006 & 40 & 8,10 & 116.551 & 2,79 \\
2007 & 42 & 5,0 & 119.972 & 2,93 \\
2008 & 44 & 4,76 & 121.851 & 1,56 \\
\hline
\end{tabular}

Sumber : PT. PLN (Persero) Wilayah IX Cabang Ambon 
Dari data di atas dapat dilihat permintaan energi listrik untuk rumah tangga industri dan rumah tangga individu menunjukan perkembangan yang berfluktuatif. Hal ini dapat dilihat pada Tahun 2003 jumlah pelanggan rumah tangga industri sebanyak 35 pelanggan sedangkan untuk rumah tangga individu sebesar 110.957 pelanggan dan kemudian pada tahun 2004 jumlah pelanggan rumah tangga industri sebesar 37 pelanggan atau naik sebesar 5,71 untuk pelanggan rumah tangga individu sebesar 113.387 pelanggan atau naik sebesar 2,19\%, tahun 2005 jumlah pelanggan rumah tangga industri 40 atau naik sebesar $8,10 \%$ untuk rumah individu 116.551 atau naik sebesar 2,79\%, kemudian tahun 2006 jumlah pelanggan rumah tangga industri 42 atau naik sebesar 5,0 untuk rumah tangga individu 119.972 atau naik sebesar 2,93, dan tahun 2010 jumlah pelanggan rumah tangga industri 44 atau naik sebesar 4,76 untuk rumah tangga individu sebesar 121.851 atau naik sebesar 1,56\%. Dari data tersebut diatas dapat dianalisa perkembangan permintaan listrik untuk rumah tangga industri dan rumah tangga individu menunjukan perkembangan yang berfluktuatif dan cenderung mengalami peningkatan.

Adapun pendapatan perkapita penduduk Kota Ambon lebih jelasnya dapat dilihat pada tabel berikut ini.

Tabel 2

Perkembangan Pendapatan Perkapita berdasarkan Harga yangBerlaku

\begin{tabular}{|c|c|c|}
\hline Tahun & $\begin{array}{c}\text { Jumlah Pendapatan } \\
\text { (Rupiah) }\end{array}$ & $\begin{array}{c}\text { Pertumbuhan } \\
(\mathbf{\%})\end{array}$ \\
\hline 2004 & 4.865 .188 & - \\
\hline 2005 & 5.321 .847 & 9,4 \\
\hline 2006 & 5.599 .625 & 5,2 \\
\hline 2007 & 6.343 .120 & 13,3 \\
\hline 2008 & 6.645 .366 & 4,8 \\
\hline
\end{tabular}

Sumber : BPS Kota Ambon 2008

Sesuai data tersebut di atas dapat dilihat perkembangan pendapatan perkapita mengalami peningkatan yang cukup signifikan adanya pertumbuhan ekonomi sangat berdampak positif terhadap peningkatan pendapatan perkapita. Hal ini dapat dilihat pada tahun 2003 jumlah pendapatan perkapita sebesar 4.865.188 kemudian pada tahun 2004 jumlah pendapatan perkapita sebesar 5.321.847 atau naik sebesar 9,4\%, tahun 2005 jumlah pendapatan perkapita sebesar 5.599.625 atau naik sebesar 5,2\%, tahun 2006 jumlah pendapatan 
perkapita sebesar 6.343 .120 atau naik sebesar 13,3\%, selanjutnya tahun 2007 jumlah pendapatan perkapita sebesar 6.645.366 atau naik sebesar 4,8\%. Diamati dari jumlah pendapatan yang menunjukan peningkatan tentunya akan berdampak positif permintaan energi listrik.

Selain faktor jumlah penduduk, pendapatan perkapita hal lain yang turut berpengaruh adalah biaya pemasangan instalasi untuk rumah tangga individu maupun rumah tangga industri dan untuk jelasnya dapat dilihat pada tabel berikut ini:

Tabel 3

Jumlah Biaya Pemasangan Instalasi Listrik untuk

Rumah Tangga Individu dan RumahTangga Industri di Kota Ambon

Tahun 2004 - 2008

\begin{tabular}{|c|c|c|c|c|}
\hline \multirow{2}{*}{ Tahun } & \multicolumn{4}{|c|}{ Biaya Pemasangan Instalasi } \\
& \multicolumn{3}{|c|}{ (Rupiah) } & \\
\cline { 2 - 5 } & $\begin{array}{c}\text { Rumah Tangga } \\
\text { Individu }\end{array}$ & $\%$ & $\begin{array}{c}\text { Rumah Tangga } \\
\text { Industri }\end{array}$ & $\%$ \\
\hline 2004 & 500.000 & - & 900.000 & - \\
\hline 2005 & 500.000 & - & 1.200 .000 & 33,3 \\
\hline 2006 & 650.000 & 10 & 1.200 .000 & - \\
\hline 2007 & 650.000 & - & I .500 .000 & 25 \\
\hline 2008 & 650.000 & - & 2.000 .000 & 33,3 \\
\hline
\end{tabular}

Sumber : Bagian Pemasaran PT. PLN Cabang Ambon Tahun 2008

Dari data tersebut di atas dapat dilihat bahwa biaya pemasangan instalasi listrik yang ditetapkan pihak PLN ternyata mengalami perkembangan yang terlalu cepat terutama bagi rumah tangga individu mengalami perkembangan yang cukup signifikan. Dengan demikian, penelitian ini dilakukan dengan tujuan utama untuk (a) mengetahui perkembangan permintaan kelistrikan di Kota Ambon, (b) menganaliasis lebih jauh tentang faktor-faktor yang mempengaruhi masyarakat terhadap listrik di Kota Ambon.

\section{METODE PENELITIAN}

Data dalam penelitian menggunakan data sekunder yaitu data siap pakai berupa laporan pendapatan yang diperoleh dari PT. PLN (Persero) Wilayah IX Maluku dan data dari Badan Pusat Statistik (BPS) Kota Ambon. Adapun identifikasi variabel adalah permintaan energi listrik (variabel Y), sedangkan penduduk, biaya pemasangan intalasi dan pendapatan perkapita masing-masing merupakan variabel bebas X1, X2, dan X3. 
Metode analisa yang digunakan dalam penelitian ini adalah dengan menggunakan regresi berganda dan guna mengetahui pengaruh variabel bebas (biaya pemasangan instalasi, pendapatan perkapita, penduduk) terhadap variabel $\neq$ dependen (permintaan energi listrik). Adapun model persamaan regresi yang digunakan dalam penelitian ini adalah sebagai berikut : (Gujarati, 2003 :203207)

$$
\mathbf{Y}=\mathbf{a}+\mathbf{b}_{1} \mathbf{x}_{1}+\mathbf{b}_{2} \mathbf{x}_{2}+\mathbf{b}_{3} \mathbf{x}_{3}+\mathbf{e}
$$

Dimana :

$$
\begin{aligned}
& \mathrm{Y}=\text { Permintaan energi listrik } \\
& \mathrm{x}_{1}=\text { Penduduk } \\
& \mathrm{x}_{2}=\text { Pendapatan perkapita } \\
& \mathrm{x}_{3}=\text { Biaya pemasangan instalasi } \\
& \mathrm{e}=\text { Error }
\end{aligned}
$$

Langkah awal adalah mencari nilai $\mathrm{b}$ sebagai parameter untuk mendapatkan persamaan seperti diatas. Dari persamaan tersebut diturunkan nilai $\mathrm{x}_{1}, \mathrm{x}_{2}, \mathrm{x}_{3}$ terhadap $\mathrm{Y}$ selanjutnya untuk membuktikan variabel $\mathrm{x}_{1}, \mathrm{x}_{2}, \mathrm{x}_{3}$ (penduduk, pendapatan perkapita, biaya pemasangan instalasi) terhadap permintaan energi listrik maka diukur dengan nilai $\mathrm{r}^{2}$ sedangkan untuk membuktikan kebenaran hipotesa apakah diterima atau ditolak digunakan kriteria penguji sebagai berikut: Ho : bo $\neq 0$ dan Ha : $b x=0$. Dimana apabila $t_{\text {hitung }}<t_{\text {tabel }}$ maka Ho (hipotesa ditolak) diterima dengan pengertian penduduk, pendapatan perkapita, biaya pemasangan tidak berpengaruh terhadap perkembangan permintaan energi listrik.

\section{PEMBAHASAN}

Perkembangan permintaan energi listrik di Kota Ambon terus mengalami peningkatan sejalan dengan lajunya pertumbuhan penduduk dan naiknya pendapatan perkapita. Namun hal ini tidak diimbangi dengan kemampuan Pembangkit Tenaga Listrik Daerah (PLTD) umur ekonomis sudah lebih dari 20 tahun sehingga kemampuan melayani sudah pada nilai ambang batas.

Sejalan dengan itu berdasarkan data yang diperoleh dari pihak PLN, penulis mengamati permintan energi listrik oleh konsumen individu dan konsumen industri dan untuk jelasnya dapat dilihat pada tabel berikut ini: 


\section{Tabel 4}

Perkembangan Jumlah Pelanggan Listrik untukRumah Tangga Industri dan Rumah TanggaIndividu di Kota Ambon

Tahun 2004 - 2008

\begin{tabular}{|c|c|c|c|c|}
\hline \multirow{2}{*}{ Tahun } & \multicolumn{4}{|c|}{ Jumlah Pelanggan } \\
\cline { 2 - 5 } & $\begin{array}{c}\text { Rumah Tangga } \\
\text { Industri } \\
\text { (Perusahaan) }\end{array}$ & $\begin{array}{c}\text { Pertumbuhan } \\
(\mathbf{\%})\end{array}$ & $\begin{array}{c}\text { Rumah Tangga } \\
\text { Individu } \\
(\mathbf{K K})\end{array}$ & $\begin{array}{c}\text { Pertumbuhan } \\
(\boldsymbol{\%})\end{array}$ \\
\hline 2004 & 35 & - & 110.957 & - \\
2005 & 37 & 5,71 & 113.387 & 2,19 \\
2006 & 40 & 8,10 & 116.551 & 2,79 \\
2007 & 42 & 5,0 & 119.972 & 2,93 \\
2008 & 44 & 4,76 & 121.851 & 1,56 \\
\hline
\end{tabular}

Sumber : PT.PLN (Persero) Wilayah IX Cabang Ambon

Dari data di atas dapat dilihat permintaan energi listrik untuk rumah tangga industri dan rumah tangga individu menunjukan perkembangan yang berfluktuatif. Hal ini dapat dilihat pada Tahun 2003 jumlah pelanggan rumah tangga industri sebanyak 35 pelanggan sedangkan untuk rumah tangga individu sebesar 110.957 pelanggan kemudian pada tahun 2004 jumlah pelanggan rumah tangga industri sebesar 37 pelanggan atau naik sebesar 5,71 untuk pelanggan rumah tangga individu sebesar 113.387 pelanggan atau naik sebesar 2,19\%. Tahun 2005 jumlah pelanggan rumah tangga industri 40 atau naik sebesar 8,10\% untuk rumah individu 116.551 atau naik sebesar 2,79\%, kemudian tahun 2006 jumlah pelanggan rumah tangga industri 42 atau naik sebesar 5,0 untuk rumah tangga individu 119.972 atau naik sebesar 2,93, dan tahun 2010 jumlah pelanggan rumah tangga industri 44 atau naik sebesar 4,76 untuk rumah tangga individu sebesar 121.851 atau naik sebesar $1,56 \%$.

Selain pelanggan yang berpengaruh pada energi listrik, faktor lain yang turut berpengaruh adalah pendapatan perkapita artinya besar kecil daya pemasangan listrik yang diminta sangat ditentukan oleh pendapatan. Berdasarkan hasil pengamatan pada beberapa konsumen dimana pemanfaatan listrik selain dijadikan pengamatan jalan/rumah juga digunakan untuk usaha - usaha produktif seperti: pembuatan es, rental play station, rental komputer, foto copy, salon dan sebagainya yang kesemuanya digunakan untuk meningkatkan pendapatan keluarga seperti tampak pada tabel 2. 
Selain faktor jumlah penduduk, pendapatan perkapita hal lain yang turut berpengaruh adalah biaya pemasangan instalasi untuk rumah tangga individu maupun rumah tangga industri. Dari tabel 3 dapat dilihat bahwa biaya pemasangan instalasi listrik yang ditetapkan pihak PLN ternyata mengalami perkembangan yang terlalu cepat terutama bagi rumah tangga individu mengalami perkembangan yang cukup signifikan.

Analisa Faktor - Faktor yang Mempengaruhi Permintaan Energi Listrik bagi Masyarakat Individu

Berdasarkan hasil pengolahan statistik dapat diketahui besar regresi sebagai berikut

$$
\begin{array}{ll}
\mathrm{Y} & =77075.999+9.904 \mathrm{x}_{1}+3.431 \mathrm{x}_{2}+4.388 \mathrm{x}_{3} \\
\text { se } & =(006)(0956)(002) \\
\mathrm{Th}_{1} & =1,782 \\
\mathrm{Th}_{2} & =358 \\
\mathrm{Th}_{3} & =2.400 \\
\mathrm{r}^{2} & =99,9 \\
\mathrm{r} & =1
\end{array}
$$

Dari persamaan di atas dapat dilihat bahwa hasil penelitian atau penjelasan data dapat diperoleh nilai $b_{1}=9.904$ artinya jika harga pemasangan instalasi naik 100.000 maka jumlah pelanggan akan bertambah sebesar 9.904 pelanggan. Nilai $\mathrm{b}_{2}=3.431$ artinya penduduk bertambah sebesar $1 \%$ maka jumlah pelanggan akan bertambah sebesar: 3.431 pelanggan untuk nilai $b_{3}=4.388$ artinya apabila pendapatan perkapita beriambah $1 \%$ maka pelanggan listrik masyarakat individu akan bertambah sebesar 4.388. Selanjutnya untuk mengetahui berapa besar nilai $r$ (korelasi) sebesar 1 sedangkan untuk melihat variabel variabel harga pemasangan, penduduk dan pendapatan perkapita terhadap tingkat perkembangan pertambahan pelanggan yang dicapai $r^{2}=99,9 \%$ sedangkan sisanya 0,1 dipengaruhi oleh variabel lain yang tidak diamati seperti gangguan pada instalasi listrik

Berdasarkan pengujian hipotesis dan menggunakan uji t. usaha diperoleh hasilnya sebagai berikut.

Th $\mathrm{x}_{1}=1,782$

Th $\mathrm{x}_{2}=358$ 
$\mathrm{Th}_{3}=2.400$

Dengan demikian dapat dijelaskan $\mathrm{t}_{\text {hitung }}<\mathrm{t}_{\text {tabel }}$

$\mathrm{x}_{1}=1.782<2.353$

$\mathrm{x}_{2}=0,358<3.353$

$\mathrm{x}_{3}=2.400<3.353$

Dari pembuktian analisa maka dapat di asumsikan bahwa dari varibel harga pemasangan, penduduk dan pendapatan perkapita ternyata yang berpengaruh secara signifikan adalah pendapatan sedangkan harga pemasangan masih bisa untuk dijangkau.

\section{Analisa - Faktor - Faktor yang Mempengaruhi Permintaan Energi Listrik bagi Masyarakat Industri}

Berdasarkan hasil olah data diperoleh persamaan sebagai berikut :

$$
\begin{array}{ll}
\mathrm{y} & =-18.558+(5,900) \mathrm{x}_{1}+2,383 \mathrm{x}_{2}+1,296 \mathrm{x}_{3}+\mathrm{e} \\
\text { se } & =(000)(000)(000) \\
\operatorname{Th~}_{1} & =2,269 \\
\operatorname{Th~}_{2} & =3,360 \\
\operatorname{Thx}_{3} & =0,858 \\
\mathrm{r}^{2} & =99,4 \% \\
\mathrm{r} & =99,8 \%
\end{array}
$$

Dari persamaan di atas dapat dilihat bahwa permintaan energi listrik untuk masyarakat industri diperoleh nilai $b_{1}(5,900)$ artinya apabila harga pemasangan instalasi naik sebesar 1\% maka jumlah pelanggan akan bertambah 5.900 kemudian nilai $b_{2}=2.383$ artinya apabila jumlah penduduk bertambah $1 \%$ maka jumlah pelanggan akan bertambah sebesar 2,383 pelanggan selanjutnya nilai $b_{3}$ $=1.296$ artinya apabila pendapatan perkapita bertambah sebesar 1\% maka pelanggan listrik untuk masyarakat individu mengalami perkembangan sebesar 1.296 pelanggan.

Selanjutnya untuk mengetahui beberapa besar hubungan secara relatif antara harga pemasangan, penduduk dan pendapatan perkapita bagi peningkatan pelanggan dapat dilihat adari nilai $\mathrm{r}^{2}=99,8 \%$ sedangkan untuk mengukur seberapa besar nilai $r=99,8$ sedangkan sisanya $0,2 \%$. Dipengaruhi oleh variabel 
lain seperti kerusakan instalasi dll. Untuk menarik kesimpulan mengenai hipotesa menolak Ho berdasarkan hasil pengolajan data dengan mengguanakan level signifikan $95 \%$ atau $5 \%$ diperoleh hasil

$$
\text { Th } \begin{aligned}
\mathrm{x}_{1} & =2,269<3.353 \\
\mathrm{x}_{2} & =3,360<3.353 \\
\mathrm{x}_{3} & =0,858<3.353
\end{aligned}
$$

Dengan demikian hipotesa alternatif yang diterima adalah $\mathrm{x}_{2}=($ Penduduk $)$ dengan kata lain apabila penduduk bertambah ada kemungkinan pelangganan rumah tangga industri mengalami perkembangan terutama industri makanan (tempe, tahu, daging, jamu, dll).

\section{Analisa Permintaan Energi Listrik untuk masyarakat individu dan masyarakat industri.}

Berdasarkan hasil penelitian lapangan di ketiga Kecamatan di Kota Ambon (Kecamatan Nusaniwe, Kecamatan Sirimau, Kecamatan Baguala) sesuai dari 10 sampel yang dipilih di ambil secara acak untuk masing-masing kecamatan dapat dilihat pada tabel berikut:

\section{Tabel 5}

Perkembangan Permintaan Energi Listrik menurut Pekerjaan, Jenis Usaha, Tingkat Pendapatan dan Pengeluaran Untuk Listrik Di Kecamatan Nusaniwe Kota Ambon

\begin{tabular}{|c|c|c|c|c|c|}
\hline $\begin{array}{c}\text { Respon } \\
\text { den }\end{array}$ & Pekerjaan & Jenis Usaha & $\begin{array}{c}\text { Daya } \\
\text { (Watt) }\end{array}$ & $\begin{array}{c}\text { Pendapat } \\
\text { an }\end{array}$ & $\begin{array}{c}\text { Pengeluaran } \\
\text { Tarif Listrik } \\
\text { (Rp) }\end{array}$ \\
\hline 1 & Swasta & Rental & 900 & 2.000 .000 & 90.000 \\
2 & Wiraswasta & Komputer & 450 & 750.000 & 30.000 \\
3 & Wiraswasta & - & 950 & 1000.000 & 200.000 \\
4 & Pensiun PNS & - & 900 & 1.300 .000 & 100.000 \\
5 & Wiraswasta & - & 900 & 800.000 & 210.000 \\
6 & PNS & Pembuatan Es & 900 & 2.350 .000 & 150.000 \\
7 & Wiraswasta & - & 900 & 1000.000 & 200.000 \\
8 & Tukang & Pembuatan Es & 900 & 500.000 & 100.000 \\
9 & Purnawirawan & - & 900 & 1.500 .000 & 250.000 \\
10 & Swasta & Salon & 900 & 2.500 .000 & 200.000 \\
\hline
\end{tabular}

Berdasarkan tabel tersebut di atas dapat dilihat pendapatan tertinggi dicapai oleh responden ke 6 dengan jumlah pendapatan sebesar Rp. 2.350.000,- 
atau sebesar $14,50 \%$ dan penggunaan listrik hanya untuk kepentingan rumah tangga misalnya masak, cuci bukan untuk usaha-usaha produktif dan hal ini mempengaruhi biaya rekening listrik yang harus dikeluarkan sebesar Rp. 150.000,- kemudian pendapatan terendah dicapai oleh responden ke 8 dengan pekerjaan sebagai tukang dengan pendapatan perbulan Rp. 500.000,- atau sebesar 3,08\% dan pengeluaran untuk listrik sebesar Rp. 100.000,- sedangkan rata-rata pendapatan masyarakat pengguna listrik di Kecamatan Nusaniwe sebesar 1.620.000.

Dari tabel tersebut diatas dapat kita asumsikan bahwa konsumen yang menggunakan energi listrik ternyata untuk usaha produktif cukup banyak namun masih bersifat home industry (Industri rumah tangga).

Tabel 6

Perkembangan Permintaan Energi Listrikmenurut Pekerjaan, Jenis Usaha, Tingkat Pendapatandan Pengeluaran Untuk Listrik di Kecamatan Sirimau Kota Ambon

\begin{tabular}{|c|c|c|c|c|c|}
\hline $\begin{array}{c}\text { Respon } \\
\text { den }\end{array}$ & Pekerjaan & Jenis Usaha & $\begin{array}{l}\text { Daya } \\
\text { (Watt) }\end{array}$ & Pendapatan & $\begin{array}{c}\text { Pengeluaran } \\
\text { Tarif Listrik } \\
(\mathbf{R p})\end{array}$ \\
\hline 1 & PNS & Kue & 2500 & 3.000 .000 & 275.000 \\
\hline 2 & Swasta & $\begin{array}{c}\text { Pembuatan } \\
\text { Makanan Jadi }\end{array}$ & 950 & 1.200 .000 & 100.000 \\
\hline 3 & Swasta & $\begin{array}{c}\text { Rental Play } \\
\text { Station }\end{array}$ & 950 & 1.000 .000 & 100.000 \\
\hline 4 & Swasta & Pembuatan Es & 950 & 2.000 .000 & 200.000 \\
\hline 5 & Swasta & $\begin{array}{c}\text { Pembuatan } \\
\text { Makanan Jadi }\end{array}$ & 900 & 1.250 .000 & 125.000 \\
\hline 6 & Swasta & Penjualan Kue & 900 & 350.000 & 50.000 \\
\hline 7 & Konsultan & - & 900 & 1.000 .000 & 1.000 .000 \\
\hline 8 & Wiraswasta & - & 900 & 1.500 .000 & 140.000 \\
\hline 9 & Wiraswasta & Penjualan Kue & 900 & 750.000 & 150.000 \\
\hline 10 & Swasta & penjahit & 900 & 300.000 & 300.000 \\
\hline
\end{tabular}

Berdasarkan tabel tersebut diatas dapat dilihat pendapatan tertinggi dicapai oleh responden ke 1 dengan jumlah pendapatan sebesar Rp. 3.000.000,- ataus ebesar 24,29\% adapun pekerjaan responden 1 adalah sebagai PNS dan memiliki usaha produktif yakni penjualan kue dan usaha-usaha lain yang dapat meningkatkan pendapatan keluarga kemudian pendapatan yang paling rendah terjadi pada responden ke 6 dengan pekerjaan sebagai wiraswasta yaitu penjualan 
kue kecil-kecilan dengan pendapatan sebesar Rp. 350.000,- atau sebesar 2,83\% dengan pembayaran rekening perbulan sebesar Rp. 50.000,-.

Dari tabel tersebut diatas dapat kita asumsikan bahwa konsumen pengguna listrik ternyata memiliki usaha produktif dan guna meningkatkan pendapatan namun diamati dari jenis usaha yang mereka tekuni hanya bersifat industri rumah tangga dan yang tidak memiliki usaha penggunaan listrik hanya untuk kebutuhan rumah tangga dan pendidikan anak yakni dengan adanya pengadaan komputer bagi anak-anak.

\section{Tabel 7}

Perkembangan Permintaan Energi Listrik menurut Pekerjaan, Jenis Usaha, Tingkat Pendapatandan Pengeluaran untuk Listrik di Kecamatan Baguala Kota Ambon

\begin{tabular}{|c|c|c|c|c|c|}
\hline Responden & Pekerjaan & Jenis Usaha & $\begin{array}{c}\text { Daya } \\
\text { (Watt) }\end{array}$ & Pendapatan & $\begin{array}{c}\text { Pengeluaran } \\
\text { Tarif Listrik } \\
\text { (Rp) }\end{array}$ \\
\hline 1 & Wiraswasta & Foto Copy & 2500 & 20.000 .000 & 1.000 .000 \\
2 & PNS & $\begin{array}{c}\text { Rental Play } \\
\text { Station }\end{array}$ & 900 & 3.000 .000 & 250.000 \\
& & & & \\
3 & Pengemudi & Penjualan Es & 900 & 850.000 & 150.000 \\
4 & Wiraswasta & $\begin{array}{c}\text { Pembuatan Es } \\
\text { Rental Play }\end{array}$ & 900 & 750.000 & 140.000 \\
5 & PNS & Station & 1.500 .000 & 100.000 \\
& & & & \\
6 & Swasta & Penjualan Kue & 900 & 1.000 .000 & 100.000 \\
7 & Wiraswasta & Salon & 900 & 2.000 .000 & 200.000 \\
8 & PNS & Penjualan Kue & 900 & 1.500 .000 & 200.000 \\
9 & Polisi & - & 900 & 3.000 .000 & 200.000 \\
10 & Swasta & Konsultan & 900 & 5.500 .000 & 250.000 \\
\hline
\end{tabular}

Berdasarkan tabel tersebut diatas dapat dilihat pendapatan tertinggi dicapai oleh res ponden ke 1 dengan pekerjaan wiraswasta yakni dengan memiliki usaha foto copy dengan jumlah pendapatan sebesar Rp. 20.000.000,- atau sebesar 51,15\%. Dengan pembayaran rekening sebesar Rp.1.000.000,- kemudian pendapatan terendah dicapai oleh responden ke 4 dengan jumlah pendapatan sebesar Rp. 750.000,- atau sebesar 1,91\% dengan jumlah pembayaran rekening listriksebesar Rp.140.000,--

Dari data diatas kita asumsikan bahwa konsumen pemakai listrik pada Kecamatan Baguala tidak hanya untuk konsumsi sendiri namun sudah tidak dapat digunakan untuk usaha-usaha produktif. Berdasarkan hasil penelitian lapangan terhadap penggunaan energi listrik maka dapat dilihat energi listrik bukan hanya 
untuk konsumsi namun telah juga digunakan usaha-usaha produktif seperti yang terjadi di Kecamatan Nusaniwe dengan pendapatan tertinggi pada responden ke 6 dengan pekerjaan PNS dengan pendapatan sebesar Rp. 2.350.000,- atau sebesar 14,25\% kemudian di Kecamatan Sirimau dengan pendapatan pada responden 1 dengan pekerjaan sebagai PNS dan memiliki usaha pembuatan kue dengan pendapatan sebesar 3000.000 atau sebesar 24,29\% selanjutnya untuk Kecamatan Baguala pendapatan tertinggi terjadi pada responden 1 dengan pekerjaan wiraswasta dengan jenis usaha foto copy dengan pendapatan sebesar Rp. 20.000.000,- atau sebesar 51,15\%.

\section{KESIMPULAN DAN SARAN}

\section{Kesimpulan}

Berdasarkan hasil analisis yang telah di lakukan diatas dapat diambil kesimpulan sebagai berikut: (1) Kota Ambon merupakan Ibu Kota Provinsi Maluku dan merupakan pusat pendidikan, pemeriniahan, perdagangan sehingga memacu arus urbanisasi sehingga setiap tahun bertambah penduduk sekaligus akan mempengaruhi permintaan energi listrik baik masyarakat individu, masyarakat industri, pemerintah dan sosial; (2) Berdasarkan hasil analisa dengan menggunakan program SPSS temyata untuk masyarakat individu nilai $b_{1}$ (harga pemasangan instalasi) sebesar 9.904 kemudian nilai $\mathrm{b}_{2}$ (penduduk) $=$ 3.431 selanjutnya nilai $b_{3}$ (pendapatan perkapita) $=4388$ artinya nilai elastisitas berpengaruh secara signifikan; (3) Diamati dari nilai hubungan (regresi) ternyata memberikan sumbangan $r=1$ sedangkan nilai korelasi $r^{2}=99,9$ artinva variabel $\mathrm{x}_{1}, \mathrm{x}_{2}, \mathrm{x}_{3}$ (harga pemasangan, penduduk, pendapatan perkapita) sangat berpengaruh terhadap peningkatan pemutusan energi listrik bagi konsumen masyarakat individu; (4) Selanjutnya untuk masyarakat industri ternyata diperoleh nilai $b_{1}(-5,900)$ kemudian nilai $b_{2}=2.383$ selanjumya nilai $b_{3}=1,296$ artinya variabel yang sangat berpengaruh adalah variabel penduduk dan pendapatan perkapita.

\section{Saran}

Dari hasil kesimpulan diatas maka ada beberapa saran yang dikemukakan sebagai berikut: (1) PLN perlu melakukan sosialisasi kepada konsumen pemakai 
listrik agar melakukan penghematan untuk menjaga ketersediaan energi listrik sehingga pasokan listrik dapat berjalan dengan baik tanpa gangguan; (2) Untuk memacu bertambahnya masyarakat industri pemerintah daerah harus dapat memberikan kemudahan-kemudahan terutama dalam tempat usaha, bantuan modal sehingga dapat memberikan lapangan usaha baru selain itu dapat menguntungkan pihak Perusahaan Listrik Negara (PLN). (3) Untuk menghemat biaya perawatan instalasi Pembangkit Listrik Tenaga Disel (PLTD) yang telah yang telah berusia 20 tahun maka pemerintah perlu untuk melakukan penggantian mesin baru.

\section{DAFTAR PUSTAKA}

Badan Pusat Statistik Kota Ambon, Kota Ambon Dalam Angka Tahun 2008.

Gardner, A. 1998. Teori Ekonomi Makro. Yogyakarta: Penerbit LPEF - UGM.

Gilarso, 2000. Pengantar Ilmu Ekonomi Bagian Makro.Yogyakarta: Penerbit Kanisisus.

Gujarati, Damodar, N. 2003. Basic Econometrics, Graw-Hill International Edition.

Kantor PT. PLN PERSERO Wilayah IX Ambon.

Nitisemito, A. S., 1982. Marketing, Cetakan Keempat, Jakarta : Penerbit Ghalia Indonesia.

Sadono Sukirno, 2002. Pengantar Ekonomi Mikro. Jakarta: Lembaga Penerbit Fakultas Ekonomi UI.

Soediyono, 1992. Ekonomi Mikro dan Permintaan-Penawaran. Yogyakarta: Penerbit Kanisisus. 
